Beata Stypułkowska

Wyższy Instytut Teologiczny w Częstochowie

\title{
Katecheza biblijna w parafii skierowana do osób dorosłych
}

Dokument Soboru Watykańskiego II, jakim jest konstytucja Dei verbum, zwraca uwagę na konieczność przeniknięcia całej działalności duszpasterskiej treściami biblijnymi ${ }^{1}$. Na ten dokument powołują się inni². Papież Benedykt XVI w adhortacji apostolskiej Verbum Domini również pisze o tym, że parafia może być środowiskiem duszpasterstwa biblijnego. Takie duszpasterstwo ma być nie tyle jedną z form duszpasterstwa, ale biblijną animacją całego duszpasterstwa, które przyczyni się do lepszego poznania osoby Chrystusa w celu osobistego spotkania z Nim, objawiającym się w swoim słowie ${ }^{3}$.

W niniejszym artykule podjęto zagadnienie katechezy biblijnej skierowanej do osób dorosłych w świetle obowiązujących dokumentów kościelnych i opracowań. Wzięto pod uwagę podstawowe dokumenty katechetyczne: adhortację apostolską Jana Pawła II o katechizacji w czasach współczesnych Catechesi tradendae ${ }^{4}$, dokument Kongregacji ds. Duchowieństwa zatytułowany Dyrektorium

\footnotetext{
${ }^{1}$ Por. Sobór Watykański II, Konstytucja dogmatyczna o Objawieniu Bożym Dei verbum [dalej: DV], 24, [w:] Sobór Watykański II, Konstytucje, Dekrety, Deklaracje. Tekst polski. Nowe tlumaczenie, Poznań 2002, s. 350-362.

${ }^{2}$ Por. Konferencja Episkopatu Polski, Dyrektorium katechetyczne Kościoła katolickiego w Polsce, Kraków 2001, 58.

${ }^{3}$ Por. Benedykt XVI, Adhortacja apostolska Verbum Domini [dalej: VD], 73, http://www.vatican. va/holy_father//benedict_xvi/apost_exhortations/documents/hf_ben-xvi_exh_20100930_verbum-domini_pl.pdf (10.02.2015).

${ }^{4}$ Jan Paweł II, Adhortacja apostolska Catechesi tradendae o katechizacji w naszych czasach [dalej: CT], [w:] Adhortacje apostolskie Ojca Świętego Jana Pawła II, t. 1 (1979-1995), Kraków 2006, s. 7-87.
} 
ogólne o katechizacji ${ }^{5}$, dokument Konferencji Episkopatu Polski zatytułowany Dyrektorium katechetyczne Kościoła katolickiego $w$ Polsce ${ }^{6}$ oraz dokument Międzynarodowej Rady do Spraw Katechezy zatytułowany Katecheza dorostych we wspólnocie chrześcijańskiej. Niektóre linie i ukierunkowania ${ }^{7}$ i następny dokument Konferencji Episkopatu Polski - Dyrektorium duszpasterstwa stużby liturgicznej $^{8}$. W artykule przedstawiono zagadnienie katechezy dorosłych w parafii ze zwróceniem uwagi na katechezę biblijną, wymieniono niektóre formy i metody katechezy biblijnej w parafii, a na końcu podano propozycje dotyczące przekazu treści biblijnych.

\section{Katecheza w parafii}

Duszpasterstwo parafialne obejmuje katechezę jako jedną z form głoszenia słowa Bożego9. Celem katechezy jest doprowadzenie katechizowanych nie tylko do spotkania z Jezusem i Jego orędziem, ale do zjednoczenia, a nawet głębokiej z Nim zażyłości (por. CT 5), która oparta jest na osobistej więzi. Czytanie i poznawanie słowa Bożego zawartego w Piśmie Świętym może przyczynić się do zapoczątkowania spotkania z żywym Bogiem, a później również prowadzić do pogłębienia relację z Chrystusem. Dyrektorium katechetyczne Kościoła katolickiego $w$ Polsce stwierdza, że jednym z zadań katechezy jest wprowadzenie chrześcijan we właściwe rozumienie Biblii i rozmiłowanie w takim jej czytaniu, aby mogli oni odkryć zawarte w niej słowo Boże i na nie odpowiedzieć (por. PDK 58). Może się to dokonywać nie tylko podczas samej katechezy, ale i liturgii. Dyrektorium zwraca uwagę na ukazanie głębokiej więzi między Pismem Świętym a liturgią (por. PDK 59). W parafii istnieje możliwość zarówno przeprowadzania liturgii słowa, jak i spotkań o charakterze studyjnym. Katecheza parafialna może przybierać różne formy duszpasterskie i może korzystać z różnych metod biblijnych.

\footnotetext{
${ }^{5}$ Kongregacja ds. Duchowieństwa, Dyrektorium ogólne o katechizacji [dalej: DOK], Poznań 1998.

${ }^{6}$ Konferencja Episkopatu Polski, Dyrektorium katechetyczne Kościoła katolickiego w Polsce [dalej: PDK], Kraków 2001.

${ }^{7}$ Międzynarodowa Rada do Spraw Katechezy, Katecheza dorostych we wspólnocie chrześcijańskiej. Niektóre linie i ukierunkowania [dalej: KDWCh], Watykan 1990. Przekład polski, tłum. K. Misiaszek, Kraków 2001.

${ }^{8}$ Konferencja Episkopatu Polski, Dyrektorium duszpasterstwa stużby liturgicznej [dalej: DDSL], Warszawa 2009.

${ }^{9}$ Por. Dyrektorium ogólne o katechizacji wymienia następujące formy posługi słowa: pierwsze głoszenie, czyli przepowiadanie misyjne, katechezę przedchrzcielną i pochrzcielną, formę liturgiczną i formę teologiczną. Zob. DOK 52.
} 
Dokumenty kościelne przedstawiają katechezę jako część szeroko pojętej ewangelizacji (por. DOK 62) ${ }^{10}$, a ewangelizację przedstawiają jako proces (por. DOK 48; PDK 54). Wymieniane są zazwyczaj trzy jej etapy (por. DOK 49; PDK $55)^{11}$. Pierwszym etapem ewangelizacji jest działanie misyjne dla niewierzących i osób obojętnych religijnie. Drugim etapem jest działanie katechetyczno-wtajemniczające dla tych, którzy wybierają Ewangelię i dla tych, którzy pragną uzupełnić lub odnowić wtajemniczenie chrześcijańskie. Trzecim etapem jest działanie duszpasterskie ukierunkowane na dojrzałych chrześcijan we wspólnocie chrześcijańskiej. Idąc śladem etapów ewangelizacji, można wyróżnić także etapy katechezy odpowiadającej wyróżnionym etapom ewangelizacji jako procesu: katechezę ewangelizacyjną ${ }^{12}$, katechezę wtajemniczającą, katechezę mistagogiczną ${ }^{13}$ i katechezę stałą. Specyficznym celem katechezy jest

${ }^{10}$ Jan Paweł II w adhortacji Catechesi tradendae wychodzi z założenia, że ewangelizacja i katecheza nie są tożsame, ale oba działania są ze sobą związane i wzajemnie się uzupełniają. Zob. CT 18.

${ }^{11}$ Por. Z. Marek, Jezus Chrystus w katechezie ewangelizacyjnej, [w:] Ewangelizować czy katechizować, red. S. Dziekoński, Warszawa 2002, s. 89.

${ }^{12} \mathrm{Na}$ temat katechezy ewangelizacyjnej oraz wzajemnych relacji między ewangelizacją a katechezą zob. P. Tomasik, Ewangelizacja-katecheza-nauczanie religii w szkole. Wyjaśnienie podstawowych terminów, [w:] Ewangelizować czy katechizować, dz. cyt., s. 23-51; tenże, Katecheza w misji ewangelizacyjnej Kościoła, „Katecheta” 42 (1998) nr 6-7, s. 9-18; A. Offmański, Model katechezy ewangelizacyjnej w dokumentach Kościoła, [w:] Ewangelizować czy katechizować, dz. cyt., s. 53-72; tenże, Katecheza jako ewangelizacja. Ewangelizacyjna funkcja katechezy, „Horyzonty wiary” 7 (1996) nr 3, s. 9-20;J. Neumann, Dlaczego katecheza ewangelizacyjna? [w:] Ewangelizować czy katechizować, dz. cyt., s. 133-143; J. Kochel, Katecheza ewangelizacyjna w nauczaniu pastoralnym Carlo Maria Kard. Martiniego, Opole 1999, s. 99-176; ; P. Nonis, Ewangelizacja a katecheza, [w:] Nowa ewangelizacja, Poznań 1993, s. 96-100 (Kolekcja Communio, 8); R. Murawski, Ewangelizacyjny charakter katechezy, „Ateneum Kapłańskie” 84 (1992) nr 2, s. 181-193; S. Łabendowicz, Katecheza w stużbie ewangelizacji, „Roczniki TeologicznoKanoniczne" 36 (1989) z. 6, s. 129-145.

${ }^{13} \mathrm{Na}$ temat katechezy mistagogicznej zob. K. Misiaszek, Mistagogia w katechezie, [w:] Mistagogia a duchowość, red. A. Żądło, Katowice 2004, s. 81-90. W tym artykule Misiaszek stwierdza, że: „W samej natomiast katechezie mistagogia jest ściśle związana z katechezą wtajemniczenia, będąc jej naturalną kontynuacją, ale także i wypełnieniem" (http://www.opoka.org. pl/biblioteka/T/TA/TAK/km_mistagogia_wk.html [3.03.2014]). Dyrektorium ogólne o katechizacji, omawiając formację katechumenalną, wskazuje na katechezę mistagogiczną, która jest etapem następującym po przyjęciu sakramentów wtajemniczenia, pomagającym w wewnętrznym przeżyciu tych sakramentów i we włączeniu się do wspólnoty. Zob. DOK 89. Również Obrzędy chrześcijańskiego wtajemniczenia dorosłych. Dostosowane do zwyczajów diecezji polskich [dalej: OCWD], Katowice 1988 okres mistagogii, czyli pogłębionego wtajemniczenia, sytuują po otrzymaniu przez wierzącego sakramentów wtajemniczenia. Wówczas cała wspólnota razem z nowo ochrzczonymi przez rozważanie Ewangelii, uczestnictwo w Eucharystii i uczynki miłosierdzia postępuje w głębszym poznaniu misterium paschalnego i usiłuje coraz lepiej urzeczywistniać je w praktyce życia. Zob. OCWD 37. 
rozwinięcie wiary początkowej, doprowadzenie do jej pełni i codzienne umacnianie życia chrześcijańskiego wiernych (por. CT 20). Domaga się to pewnych etapów i rozłożenia działania katechetycznego w czasie, uwzględniając również osoby dorosłe.

Normy, kryteria i propozycje dotyczące katechezy zamieszczone w Dyrektorium ogólnym o katechizacji dotyczą w zasadzie katechezy parafialnej ${ }^{14}$. Dokument ten zwraca uwagę, że katecheza wtajemniczająca dorosłych, dzieci i młodzieży oraz katecheza stała powinny być ze sobą powiązane i zintegrowane (por. DOK $72)^{15}$. Istotnym zadaniem katechezy wtajemniczającej jest wprowadzenie w pełnię życia chrześcijańskiego (por. CT 18; DOK 63). Prowadzi ona do owocnego przyjęcia sakramentów wtajemniczenia chrześcijańskiego (por. DOK 66): chrztu, bierzmowania i Eucharystii (por. DOK 65). Chrzest związany jest ściśle z wyznaniem wiary, co jest również celem katechezy (por. DOK 66). Katecheza ma być uporządkowanym i systematycznym wprowadzeniem w Objawienie zachowane w tradycji Kościoła i w Piśmie Świętym (por. CT 22; DOK 66). Katecheza wtajemniczająca jest katechezą podstawową (por. CT 21; DOK 67, 69), skoncentrowaną na Osobie Jezusa Chrystusa (por. DOK 67). Istotnym elementem wtajemniczenia chrześcijańskiego jest również zrozumienie ścisłej więzi Biblii z liturgią (por. PDK 59). W liturgii natomiast czytane są teksty zarówno z Nowego, jak i Starego Testamentu, co wskazuje na potrzebę wprowadzania katechizowanych już na początkowym etapie w całość orędzia biblijnego, a nie tylko w treść Ewangelii. Jedność i harmonia obu Testamentów, oparta na chrystocentryzmie, powinna być elementem konstytutywnym współczesnej katechezy biblijnej na wzór katechezy apostolskiej i patrystycznej (por. PDK 59). Katecheza stała skierowana jest do chrześcijan już wprowadzonych w podstawowe elementy, które powinny ożywiać i prowadzić ich wiarę do dojrzałości w ciągu całego życia (por. DOK 51 wraz z przyp. 64). Katecheza stała zakłada katechezę wtajemniczającą. Skierowana jest nie tylko do każdego wierzącego, ale także do wspólnoty chrześcijańskiej, od której wymaga wierności wobec działania Ducha Świętego, ciągłego karmienia się Eucharystią i stałego wychowania wiary przez słuchanie słowa (por. DOK 70). Wśród form katechezy stałej Dyrektorium ogólne o katechizacji wymienia studium i pogłębienie Pisma Świętego czytanego nie tylko w Kościele, lecz także z Kościołem (por. DOK 71).

${ }^{14}$ Por. R. Murawski, Działania katechetyczne w parafii w świetle Dyrektorium ogólnego i polskiego, [w:] Przesłanie dokumentów katechetycznych Kościoła w Polsce, red. S. Dziekoński, Warszawa 2003, s. 56.

${ }^{15}$ Por. R. Murawski, Działania katechetyczne w parafii..., dz. cyt., s. 60-61. 


\section{Katecheza biblijna dorosłych}

Dyrektorium katechetyczne Kościoła katolickiego w Polsce omawia temat duszpasterstwa katechetycznego w parafii, rozpoczynając od zagadnienia katechezy dorosłych. Katecheza dorosłych realizuje się prawie w całości w para$\mathrm{fii}^{16}$. Katecheza w parafii natomiast w szczególny sposób winna być ukierunkowana na dorosłych ${ }^{17}$. Katecheza dorosłych winna być podjęta przez parafię jako jej priorytet duszpasterski ${ }^{18}$. Pytanie o koncepcję katechezy dorosłych wiąże się ściśle z pytaniem o koncepcję parafii ${ }^{19}$. Parafia, która jest rzeczywistą wspólnotą wiernych ${ }^{20}$, wypełnia zadania jednoczenia ich w wierze, kulcie i miłości braterskiej ${ }^{21} \mathrm{i}$ tym samym podsuwa istotne tematy formacyjne dla katechezy dorosłych.

Dokumenty katechetyczne zaznaczają, że duszpasterstwo katechetyczne powinno mieć charakter ciągły, co oznacza, że katecheza dzieci, katecheza młodzieży i katecheza dorosłych nie mogą być od siebie oddzielone ani pozbawione wzajemnej łączności (por. CT 45; DOK 171; PDK 97; KDWCh 29).

Katecheza ciągła odnosi się do ciągłego duszpasterstwa katechetycznego w tym sensie, że katecheza dzieci, młodzieży i dorosłych jest ze sobą powiązana, tworząc pewien ciąg katechetycznego nauczania ${ }^{22}$. Katecheza dzieci zaszczepia i rozwija wiarę, katecheza młodzieży formuje zdecydowaną postawę wiary, natomiast katecheza dorosłych ma doprowadzić do ukształtowania wiary wspólnotowej23

$\mathrm{Na}$ etapie katechezy ewangelizacyjnej i wtajemniczającej katechizowany zapoznaje się głównie z treścią Ewangelii oraz historią biblijną. W założeniach katechetycznych w odniesieniu do dzieci i młodzieży nie ma mowy o zapoznaniu uczniów w sposób systematyczny z wszystkimi księgami biblijnymi, ani nawet

${ }^{16}$ Por. S. Łabendowicz, Katecheza dorostych Kościoła posoborowego w świetle dokumentów i literatury katechetycznej, Radom 2007, s. 338-350.

${ }^{17}$ Por. M. Duda, Myślac parafia... Papieża Jana Pawła II wizja parafii. Studium teologicznopastoralne, Częstochowa 2006, s. 257.

${ }^{18}$ Por. tamże, s. 258.

${ }^{19}$ Por. P. Tomasik, Miejsce katechezy dorostych $w$ duszpasterstwie polskim, [w:] Katecheza dorostych we wspólnocie Kościoła, red. K. Misiaszek, Warszawa 2002, s. 214; F. Woronowski, Zarys teologii pastoralnej, t. 3, Warszawa 1988, s. 23-30.

${ }^{20}$ Por. M. Duda, Soborowa i posoborowa wizja parafii, [w:] tegoż, Parafia - kawatek nieba ... do moich Parafian i nie tylko... 1996-2003, Częstochowa 2004, s. 191-197.

${ }^{21}$ Por. R. Kamiński, Duszpasterstwo w społeczeństwie pluralistycznym, Lublin 1997, s. 66; E. Sztafrowski, Urzeczywistnianie się Kościoła w duszpasterstwie parafialnym, [w:] Duszpasterstwo w świetle nowego Kodeksu Prawa Kanonicznego, red. J. Syryjczyk, Warszawa 1985, s. 57-58.

${ }^{22}$ Por. R. Murawski, Działania katechetyczne w parafii..., dz. cyt., s. 66.

${ }^{23}$ Por. A. Potocki, Katecheza dorostych w przemianie, [w:] Katecheza dorostych we wspólnocie Kościoła, dz. cyt., s. 69; M. Majewski, Idee przewodnie katechezy dorostych, „Roczniki TeologicznoKanoniczne" 4 (1977), s. 158. 
w całości z Nowym Testamentem. Uczeń może ukończyć edukację szkolną, nie przeczytawszy w całości Pisma Świętego. Ten szkolny brak można uzupełnić przez katechezę parafialną dorosłych. W pewnym uproszczeniu katechezę dorosłych utożsamia się z ich teologicznym kształceniem ${ }^{24}$ i w tym sensie można by też mówić o formacji biblijnej. Jednakże, choć każda katecheza zawiera pewien zasób wiedzy ${ }^{25}$, nie jest ograniczona tylko do wymiaru intelektualnego. W katechezie chodzi o działanie duszpasterskie, którego celem jest doprowadzenie katechizowanego nie tylko do spotkania z Chrystusem, ale i do zjednoczenia, a nawet głębokiej z Nim zażyłości (por. CT 5). Może się to odbywać przy pomocy Pisma Świętego poznawanego w parafii. Systematyczne kształcenie teologiczne natomiast lepiej uznać za dalszy etap katechezy ${ }^{26}$, który przygotuje wiernych do apostolstwa ${ }^{27}$. W odniesieniu do dorosłych możemy mieć do czynienia z katechezą ewangelizacyjną, wtajemniczającą i stałą. Wówczas na etapie katechezy ewangelizacyjnej oraz katechezy wtajemniczającej podobnie jak w przypadku katechezy dzieci i młodzieży podstawowych treści biblijnych dostarczy Ewangelia i historia biblijna. Na dalszym etapie - katechezy stałej - można mówić o systematycznym wprowadzaniu katechizowanych w cały kanon biblijny.

Dyrektorium katechetyczne Kościoła katolickiego w Polsce zaznacza, że każda wspólnota winna zapewnić wszystkim dorosłym stosowną do ich wieku, wykształcenia, stanu, zawodu oraz zainteresowania formę katechezy (por. PDK 101) ${ }^{28}$. Mogą to być: kursy katechezy systematycznej, jak np. kursy biblijne; formy katechezy okazjonalnej, uwzględniającej różne sytuacje i okoliczności, domagające się światła orędzia Bożego (por. PDK 101); katecheza podejmowana przez ruchy, stowarzyszenia i organizacje katolickie, zwłaszcza Akcję Katolicką (por. PDK 102)29;

${ }^{24}$ Por. A. Potocki, Katecheza dorostych w przemianie, dz. cyt., s. 65.

${ }^{25}$ Por. R. Murawski, Kierunki i formy pracy katechetycznej z dorostymi w parafii, „Śląskie Studia Teologiczno-Historyczne" 13 (1980), s. 66.

${ }^{26}$ Por. A. Potocki, Katecheza dorostych w przemianie, dz. cyt., s. 65.

${ }^{27}$ Por. Dyrektorium apostolstwa świeckich, 104, [w:] Komisja Episkopatu polski duszpasterstwa ogólnego, Program duszpasterski na rok 1994/95. Ewangelizacja w tajemnicy i misji Kościoła. Materiaty formacyjne i homiletyczne w roku duszpasterskim 1994/95, Katowice 1994, s. 372.

${ }^{28}$ Por. P. Tomasik, Miejsce katechezy dorostych $w$ duszpasterstwie polskim, dz. cyt., s. 227-228.

${ }^{29} \mathrm{O}$ ruchach i stowarzyszeniach wspomina również dokument Międzynarodowej Rady do Spraw Katechezy Katecheza dorosłych we wspólnocie chrześcijańskiej - [dalej: KDWCh] 63. Należy zauważyć, że katecheza prowadzona w ramach ruchów i stowarzyszeń może być ograniczona do określonego charyzmatu danego ruchu czy stowarzyszenia. Nie jest jej celem przekazywanie całokształtu prawd Objawienia w sposób usystematyzowany ani też zapoznanie z orędziem biblijnym. Katechetycy zwracają uwagę, że nie należy utożsamiać katechezy dorosłych z różnorodnymi ruchami i stowarzyszeniami (K. Misiaszek, Zagadnienie katechezy dorostych wedtug dokumentu ,Katecheza dorostych we wspólnocie chrześcijańskiej”, [w:] Katecheza dorostych we wspólnocie Kościoła, dz. cyt., s. 58-59; S. Łabendowicz, Katecheza dorostych Kościoła posoborowego w świetle dokumentów 
rekolekcje zamknięte (por. PDK 104); katecheza w trakcie pieszych i autokarowych pielgrzymek do sanktuariów (por. PDK 104); katecheza w ramach duszpasterstwa masowego w formie niedzielnej homilii (por. PDK 102); katecheza odnosząca się do problematyki zawartej w programie duszpasterskim danego roku kościelnego, również w ramach kazań głoszonych z racji nabożeństw pasyjnych na gorzkich żalach i nabożeństw okresowych w maju, czerwcu i październiku ${ }^{30}$, a także kazań eucharystycznych w okresie oktawy Bożego Ciała (por. PDK 117); katecheza adresowana do rodziców w ramach przygotowania do sakramentów świętych ich dzieci (por. PDK 103) 31 ; doroczne rekolekcje oraz całotygodniowe misje (por. PDK 117) i inne formy podane w Dyrektorium ogólnym o katechizacji (176). Żywotność duszpasterska parafii zależy od istniejących w niej różnych, wzajemnie uzupełniających się form katechezy dorosłych (por. PDK 101).

Wskazówki dotyczące katechezy dorosłych odnoszą się do dorosłych świeckich (por. PDK 98, 101; DOK 174; KDWCh 26, 50) ${ }^{32}$. Dyrektoria katechetyczne wyróżniają trzy grupy dorosłych, które powinny być objęte katechezą dorosłych. Pierwszą grupę stanowią dorośli wierzący, którzy spójnie przeżywają swój wybór wiary i pragną jej pogłębienia. Do nich będzie skierowana katecheza stała. Druga grupę katechizowanych stanowią dorośli, którzy zostali ochrzczeni, lecz oddalili

i literatury katechetycznej, Radom 2007, s. 356), ponieważ nie wszyscy dorośli do nich należą. Zob. PDK 102; KDWCh 63. Jednakże w odniesieniu do formacji biblijnej nie sposób nie docenić wielu ruchów, które wdrażają swoich członków do pogłębionego czytania i rozważania Pisma Świętego (Ruch Światło-Życie, Domowy Kościół, Neokatechumenat i inne).

${ }^{30}$ Bibliści od wielu lat proponują wykorzystanie nabożeństw październikowych na biblijne pogłębienie tajemnic różańcowych, zawsze z krótkim komentarzem. Zob. J. Kudasiewicz, Proforystyka pastoralna. Pismo Święte jako księga Ludu Bożego, [w:] Wstęp ogólny do Pisma Świętego, red. J. Szlaga, Poznań-Warszawa 1986, s. 271-272; tenże, Pismo św. w naszej parafii, „Kielecki Przegląd Diecezjalny” 40 (1964), s. 178; S. Łach, Pismo św. w rodzinach katolickich, „Homo Dei” 19 (1950) nr 4-5, s. 677.

${ }^{31}$ Murawski zwraca uwagę na priorytetowe znaczenie tej formy katechezy i rozciąga ją na katechizację różnych grup dzieci uczęszczających na katechezę, a więc katechizację rodziców posiadających dzieci w wieku przedszkolnym i następnie uczących się w różnych typach szkół. Zob. tenże, Kierunki i formy pracy katechetycznej z dorosłymi, s. 74-75. Zob. również: S. Łabendowicz, Katecheza dorostych..., dz. cyt., s. 345; J. Majka, Problem katechizacji dorostych na tle współczesnej rzeczywistości religijno-społecznej, [w:] Powołanie człowieka. W służbie Ludowi Bożemu, red. B. Bejze, t. 6, Poznań-Warszawa 1983, s. 452-455, 461; E. Majcher, Wspótudziat rodziców w katechizacji parafialnej, [w:] Powołanie człowieka, dz. cyt., s. 448-450.

${ }^{32} \mathrm{~W}$ odniesieniu do katechezy dorosłych warto zwrócić jeszcze uwagę na dokument zatwierdzony w 1970 roku przez Konferencję Episkopatu Polski, a mianowicie Dyrektorium apostolstwa świeckich, [w:] Komisja Episkopatu Polski ds. Duszpasterstwa Ogólnego, Ewangelizacja w tajemnicy i misji Kościoła. Materiały formacyjne i homiletyczne w roku duszpasterskim 1994/95, Katowice 1994, s. 352-375 oraz Adhortację apostolską Jana Pawła II o powołaniu i misji świeckich w Kościele dwadzieścia lat po Soborze Watykańskim II Christifideles laici. 
się od wiary. Ta grupa potrzebuje katechezy ewangelizacyjnej i wtajemniczającej. Podobnie jak trzecia grupa, którą stanowią dorośli nieochrzczeni (PDK 99; DOK 172). Dyrektorium ogólne o katechizacji mówi o katechezie w szczególnych sytuacjach i środowiskach, z uwzględnieniem różnych mentalności.

Wymieniona jest katecheza niepełnosprawnych i nieprzystosowanych (por. DOK 189), katecheza zepchniętych na margines (por. DOK 190), katecheza dla grup zróżnicowanych (por. DOK 191) oraz katecheza środowiskowa (por. DOK 192). Również Dokument Międzynarodowej Rady do Spraw Katechezy zatytułowany Katecheza dorosłych we wspólnocie chrześcijańskiej wśród odbiorców katechezy dorosłych wyróżnia tych, którzy są pozostawieni na marginesie życia: niepełnosprawni fizycznie i psychicznie, osoby w podeszłym wieku, chorzy i najbardziej zagrożeni życiową marginalizacją (uchodźcy, emigranci, nomadzi, więźniowie) (por. KDWCh 55). Te osoby w zależności od swojej kondycji religijnej mogą potrzebować różnych form katechezy. Dyrektorium katechetyczne Kościoła katolickiego w Polsce zwraca uwagę na katechezę dorosłych adresowaną do rodziców w ramach przygotowania ich dzieci do sakramentów świętych: chrztu, Pierwszej Komunii Świętej i sakramentu pokuty, rocznicy Pierwszej Komunii Świętej oraz sakramentu bierzmowania (por. PDK 103) ${ }^{33}$. Dla tej grupy wskazana jest katecheza wtajemniczająca skoncentrowana na sakramentach, które będą przeżywane w rodzinie. Pogłębienie przeżywania sakramentów wtajemniczenia chrześcijańskiego przez rodziców wpłynie na bezpośrednie przygotowanie się do przyjęcia tych sakramentów przez dzieci.

Wśród celów szczegółowych katechezy dorosłych dokument Międzynarodowej Rady do Spraw Katechezy zatytułowany Katecheza dorostych we wspólnocie chrześcijańskiej wymienia osiągnięcie podstawowego stopnia rozumienia wiary Kościoła, dostatecznie spójnej i umotywowanej, odwołującej się bezpośrednio do źródeł Objawienia, tj. Pisma Świętego, liturgii, ojców Kościoła, Magisterium Kościoła, do innych wielkich dokumentów Tradycji oraz do doświadczeń życia wspólnot kościelnych (por. KDWCh 39). Dalej celem katechezy jest nabycie przez dorosłych odpowiedniej znajomości dziedzictwa teologicznego i kulturowego, poprzez które przekazuje się dzisiaj wiarę, a więc odkrycie m.in. roli Pisma Świętego oraz dojrzałe rozumienie znaczenia i praktyki modlitwy liturgicznej i prywatnej,

${ }^{33}$ Katecheza adresowana do rodziców może być zachętą do rodzinnego czytania Pisma Świętego. Bibliści sugerują, że lektura rodzinna winna być regularna: codzienna lub cotygodniowa. Lektura codzienna powinno mieć charakter kursoryczny, a lektura cotygodniowa - najlepiej w wigilie niedziel i świąt - charakter liturgiczny, tzn. jako lekturę można wybrać perykopy biblijne przypadające na dane święto według porządku czytań. Zob. J. Kudasiewicz, Proforystyka pastoralna..., dz. cyt., s. 272-273; R. Kamiński, Biblia w życiu parafii i małych wspólnot religijnych, [w:] Biblia w nauczaniu chrześcijańskim, red. J. Kudasiewicz, Lublin 1991, s. 165-166. 
a także podjęcie wysiłku na rzecz obecności wiary chrześcijańskiej w kulturze i instytucjach życia publicznego (por. KDWCh 40). Kolejnymi celami katechezy są: zdobycie zdolności chrześcijańskiego rozumienia sytuacji życiowych i osiągnięcie takich kompetencji i sprawności, które sprawią, że wierzący stanie się zdolny do dawania chrześcijańskiego świadectwa (por. KDWCh 41-42). Treści katechezy dorosłych koncentrują się wokół wielkich tematów religii chrześcijańskiej, jakimi są: misterium Boga i Trójcy Świętej, Chrystusa, Kościoła, sakramentów, życia ludzkiego, wartości etycznych, rzeczywistości eschatologicznych i innych aktualnych problemów w dziedzinie religijnej i moralnej (por. KDWCh 43). Pismo Święte może być źródłem dla ukazywania w katechezie tych tematów. Zadaniem katechezy jest również pomoc w poznawaniu i ocenie rzeczywistości społeczno-kulturowej w świetle wiary, wyjaśnienie różnicy między działaniem w porządku doczesnym a kościelnym i między zaangażowaniem politycznym a ewangelizacyjnym, ukazując ich powiązania i wzajemne wpływy (por. KDWCh 45). Aby zrealizować to zadanie, potrzebne jest wdrażanie do modlitewnej lektury Pisma Świętego, dzięki której wierzący w świetle słowa Bożego może rozeznawać swoje powołanie i podejmować życiowe decyzje. W katechezie dorosłych należy zadbać o odpowiednie przygotowanie jej uczestników i całej wspólnoty do czytania, rozumienia i wykorzystywania Pisma Świętego, jak również do uczestniczenia w liturgii i praktykowania modlitwy (por. KDWCh 46).

Dokumenty katechetyczne nie wspominają o katechezie dorosłych posługujących w liturgii. Dyrektorium katechetyczne Kościoła katolickiego w Polsce mówi o zespołach liturgicznych tylko w odniesieniu do dzieci i młodzieży, nie

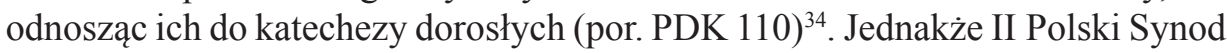
Plenarny w odniesieniu do parafii zaleca zespoły liturgiczne, które złożone są z dorosłych, młodzieży i dzieci ${ }^{35}$. Podobnie wypowiada się Dyrektorium duszpasterstwa stużby liturgicznej $(3,54,100-146)$. W tym ostatnim dokumencie zwrócono uwagę, że zaangażowanie dorosłych w służbę liturgiczną rozwija się dwiema drogami: jako kontynuacja posługiwania, które ktoś podejmował w dzieciństwie i młodości oraz jako podjęcie posługi w wieku dorosłym (por. DDSL 100). Dla tych ostatnich wskazany jest krótki okres wprowadzający (por. DDSL 104), a następnie trzyletnia formacja wstępna, koncentrująca się na tych tematach,

\footnotetext{
${ }^{34}$ Nie brak natomiast pozycji o związku katechezy dorosłych z liturgią, zob. W. Nowak, Katecheza dorostych i liturgia, [w:] Katecheza dorostych w teorii i praktyce. Impulsy - wyzwania - perspektywy, red. C. Rogowski, Lublin-Olsztyn 2001, s. 137-157. W podanym artykule mowa jest o przygotowaniu dorosłych do celebrowania misterium Chrystusa w liturgii, bez wskazania możliwości podjęcia w czasie liturgii różnych posług, które mogą spełniać świeccy.

${ }^{35}$ Liturgia Kościoła po Soborze Watykańskim II, 83, [w:] II Polski Synod Plenarny (1991-1999), Poznań 2001.
} 
które podejmują młodzieżowe zespoły liturgiczne: słowo (por. DDSL 91-92), sakrament (por. DDSL 93-94), wspólnota (por. DDSL 95-96). Pierwszy rok koncentruje się na głębszym wprowadzeniu w słowo Boże. Jednakże uwzględniając trzyletni niedzielny cykl czytań mszalnych (rok A, B i C) oraz dwuletni cykl dni powszednich (Rok I i II), należy liczyć się z potrzebą kilkuletniego okresu wprowadzania dorosłych w teksty biblijne czytane w czasie liturgii, a później $\mathrm{z}$ biblijną formacją permanentną.

\section{Niektóre formy i metody katechezy biblijnej dorosłych w parafii}

W dydaktyce „forma nauczania” jest to termin oznaczający organizacyjną stronę nauczania, w odróżnieniu od metody nauczania, która dotyczy sposobu pracy nauczyciela z uczniami. Forma nauczania obejmuje zewnętrzne warunki nauczania, a więc dobór uczniów i nauczycieli, połączenie ich w odpowiednie grupy, współpracę grup i jednostek ze sobą, rodzaj zajęć oraz warunki miejsca i czasu pracy dydaktycznej ${ }^{36}$. Dydaktycy dzielą formy nauczania ze względu na liczbę uczniów (nauczanie jednostkowe, w grupach, zbiorowe), miejsce (zajęcia szkolne i pozaszkolne) i czas trwania zajęć dydaktycznych (zajęcia lekcyjne i pozalekcyjne) $)^{37}$. Metodą nauczania zwykło się określać systematycznie stosowany sposób pracy nauczyciela z uczniami, umożliwiający osiągnięcie celów kształcenia $^{38}$. Dydaktycy w różny sposób dzielą metody nauczania ${ }^{39}$. W niektórych dawniejszych pozycjach można spotkać się z utożsamianiem metody z formą nauczania ${ }^{40}$.

${ }^{36}$ Por. W. Okoń, Nowy słownik pedagogiczny, Warszawa 1996, s. 77-78.

${ }^{37}$ Por. C. Kupisiewicz, Podstawy dydaktyki ogólnej, Warszawa 1995, s. 187-189.

${ }^{38}$ Por. W. Okoń, Nowy stownik pedagogiczny, dz. cyt., s. 168.

${ }^{39}$ Por. C. Kupisiewicz, Podstawy dydaktyki ogólnej, dz. cyt., s. 137-140; W. Okoń, Nowy stownik pedagogiczny, dz. cyt., s. 168-169.

${ }^{40}$ Por. W. Okoń, Nowy stownik pedagogiczny, s. 78. Z taką sytuacją mamy w odniesieniu do przedstawienia form duszpasterstwa biblijnego, gdzie autor wymienia jako formy biblijne: medytację biblijną, nabożeństwo słowa Bożego, godzinę biblijną, kręgi biblijne, rewizję życia w świetle Ewangelii. Z podobną sytuacją mamy do czynienia w nowszym wydaniu Wstępu ogólnego do Pisma Świętego. Autor w obu przypadkach niekiedy zamiennie stosuje terminy „forma” i „metoda”. Zob. J. Kudasiewicz, Pismo Święte jako księga ludu Bożego i jej znaczenie duszpasterskie, [w:] Wstęp ogólny do Pisma Świętego, red. J. Homerski, Poznań-Warszawa 1973, s. 367-388; J. Kudasiewicz, Proforystyka pastoralna..., dz. cyt., s. 250-269. W nowszej pozycji inny autor godzinę biblijną, kręgi biblijne, ewangeliczną rewizję życia zalicza do metod biblijnych. Zob. R. Kamiński, Biblia w życiu parafii i małych wspólnot religijnych, dz. cyt., s. 154-168. 
Dokumenty kościelne posługują się dydaktycznymi pojęciami formy i metody w odniesieniu do działalności katechetycznej ${ }^{41}$. Gdy mowa jest o ogólnych założeniach dotyczących sposobu realizacji katechezy, stosowany jest wówczas termin „forma” (por. DOK 176, 185; PDK 98, 102-103), natomiast gdy mowa jest o konkretnych sposobach katechizacji używany jest wtedy termin „metoda” (por. DOK 148-151, 156, 157). W dydaktyce katechetycznej podejmowane są próby sklasyfikowania form kształcenia religijnego ${ }^{42}$.

Stosując terminy dydaktyczne, można przyjąć w parafii trzy formy organizowania katechezy biblijnej: formy modlitewne, studyjne i mieszane.

W parafii przede wszystkim jest miejsce na modlitwę słowem Bożym. Dostępne formy modlitewne to przede wszystkim nabożeństwo słowa Bożego ${ }^{43}$, liturgia godzin ${ }^{44}$, w dalszej kolejności adoracje i nabożeństwa okresowe, podczas których można przybliżać wiernym Pismo Święte. Stosując te formy można wykorzystać różne metody biblijne, takie jak np. nabożeństwo różańcowe według metody Jana Pawła II ${ }^{45}$, w której podkreślony został moment słuchania słowa Bożego ${ }^{46}$ oraz metoda lectio divina ${ }^{47}$.

${ }^{41}$ Por. J. Szpet, Dydaktyka katechezy, Poznań 1999, s. 118.

${ }^{42}$ Por. tamże, s. $118-119$.

${ }^{43}$ Por. J. Kudasiewicz, Proforystyka pastoralna, dz. cyt., s. 255-258.

${ }^{44}$ Benedykt XVI w swojej adhortacji Verbum Domini zwrócił uwagę na to, że: „Synod wyraził pragnienie, by bardziej upowszechnił się wśród ludu Bożego ten typ modlitwy, zwłaszcza odmawianie Jutrzni i Nieszporów. To rozpowszechnienie z pewnością pogłębi znajomość słowa Bożego wśród wiernych. Trzeba uwydatnić również znaczenie Liturgii Godzin przewidzianej na pierwsze Nieszpory niedzieli i uroczystości, w szczególności w przypadku katolickich Kościołów Wschodnich. W tym celu zalecam, aby tam, gdzie to jest możliwe, w parafiach i wspólnotach życia zakonnego ta modlitwa była odmawiana z udziałem wiernych" (VD 62).

${ }^{45}$ Por. Jan Paweł II, List apostolski o różańcu świętym Rosarium Virginis Mariae [dalej: RVM], 29-37.

${ }^{46}$ Jan Paweł II w następujący sposób wyjaśnia, na czym może polegać słuchanie słowa Bożego podczas odmawiania różańca: „Aby dać medytacji podstawy biblijne i większą głębię, dobrze jest, po zapowiedzi tajemnicy, odczytać odnośny tekst biblijny, który, zależnie od okoliczności, może być krótszy albo dłuższy. Inne słowa nie są bowiem nigdy tak skuteczne, jak Słowo natchnione. Należy go słuchać, mając pewność, że jest to Słowo Boga, wypowiedziane na dzisiaj i «dla mnie». Przyjęte w ten sposób, wchodzi ono w różańcową metodologię powtarzania, nie powodując znużenia, jakie wywoływałoby zwykłe powtarzanie informacji dobrze już przyswojonej. Nie chodzi bowiem o przywoływanie na pamięć informacji, ale o to, by pozwolić Bogu «mówić». Przy pewnych uroczystych okazjach wspólnotowych słowo to można odpowiednio objaśnić krótkim komentarzem" (RVM 30).

${ }^{47}$ Kochel zwraca uwagę na to, że papież Benedykt XVI jest wielkim propagatorem metody lectio divina. Zachęcał do stosowania tej metody młodych w Orędziu na XXI Światowy Dzień Młodzieży w 2006 roku oraz poświęcił jej miejsce w adhrotacji Verbum Domini (nr 74). Zob. J. Kochel, Katecheci w stużbie słowa Bożego, [w:] J. Kochel, Z. Marek, Pedagogia biblijna w ka- 
W parafii możliwe jest również zorganizowanie form studyjnych służących zgłębianiu Pisma Świętego. Mogą odbywać się spotkania w małych grupach, w większych zespołach (np. róże różańcowe) oraz praca indywidualna. Formy studyjne również zawierają modlitwę słowem Bożym, gdyż Pismo Święte jest poznawane w odniesieniu do spotkania z Chrystusem. Wśród metod studyjnych możemy wyróżnić: godzinę biblijną ${ }^{48}$, kręgi biblijne ${ }^{49}$, metodę Västers ${ }^{50}$, rewizję życia w świetle Biblii ${ }^{51}$, metodę tzw. krótkich formuł wiary ${ }^{52}$, metodę dzielenia się Ewangelią ${ }^{53}$, metodę rozmowy ewangelicznej ${ }^{54}$, metodę wspólnot neokatechumenalnych ${ }^{55}$, metodę fokolarynów ${ }^{56}$, metodę Karola Mestersa ${ }^{57}$. Możliwe do wykorzystania w pracy parafialnej są również metody biblijne stosowane w szkole ${ }^{58}$.

W parafii można zorganizować także formy mieszane: modlitewno-studyjne, np. podczas dnia biblijnego, kiedy jest miejsce zarówno na modlitwę słowem Bożym, jak i na prowadzenie w małych grupach poszukiwania odpowiedzi na pytania problemowe. Do takich form duszpasterstwa biblijnego można zaliczyć

techezie, Kraków 2012, s. 156-157. Na temat metody lectio divina zob. „,Uważajcie jak stuchacie” (Łk 8, 18). Teoria i praktyka , lectio divina”, red. H. Witczyk, S. Haręzga, Kielce 2003; M. Masini, Wprowadzenie do , lectio divina”. Teologia, metoda, duchowość, praktyka, tłum. B. Żurowska, Kraków 2001; J. Kudasiewicz, Modlitwa Biblią. Wprowadzenie do ,,lectio divina”, Kielce 2000; K. Wons, Jak żyć stowem Bożym na co dzień, Kraków 2000; W. Zatorski, Ustyszeć stowo Boże. Praktyka „lectio divina”, Kraków 1999; E. Bianchi, Przemodlić Stowo. Wprowadzenie do lectio divina, tłum. A. Tronina, Kraków-Tyniec 1998.

${ }^{48}$ Por. J. Kudasiewicz, Proforystyka pastoralna, dz. cyt., s. 259-264; R. Kamiński, Biblia w życiu parafii i małych wspólnot religijnych, dz. cyt., s. 154-155.

${ }^{49}$ Por. J. Kudasiewicz, Proforystyka pastoralna, dz. cyt., s. 264-266; R. Kamiński, Biblia w życiu parafii i małych wspólnot religijnych, dz. cyt., s. 155-156.

${ }^{50}$ Por. R. Kamiński, Biblia w życiu parafii i małych wspólnot religijnych, dz. cyt., s. 156-157;

A. Długosz, B. Stypułkowska, Wprowadzenie do dydaktyki biblijnej, Kraków 2000, s. 114.

${ }^{51}$ Por. J. Kudasiewicz, Proforystyka pastoralna, dz. cyt., s. 266-269; R. Kamiński, Biblia w życiu parafii i małych wspólnot religijnych, dz. cyt., s. 157-158.

${ }^{52}$ Por. R. Kamiński, Biblia w życiu parafii i małych wspólnot religijnych, dz. cyt., s. 158.

${ }^{53}$ Por. tamże, s. 158-159; A. Długosz, B. Stypułkowska, Wprowadzenie do dydaktyki biblijnej, dz. cyt., s. 113.

${ }^{54}$ Por. R. Kamiński, Biblia w życiu parafii i matych wspólnot religijnych, dz. cyt. s. 159-160; A. Długosz, B. Stypułkowska, Wprowadzenie do dydaktyki biblijnej, dz. cyt., s. 113.

${ }^{55}$ Por. R. Kamiński, Biblia w życiu parafii i małych wspólnot religijnych, dz. cyt., s. 160-162; A. Długosz, B. Stypułkowska, Wprowadzenie do dydaktyki biblijnej, dz. cyt., s. 114-115.

${ }^{56}$ Por. C. Lubich, Klucz do jedności, Katowice 1989, s. 102-106; R. Kamiński, Biblia w życiu parafii i małych wspólnot religijnych, dz. cyt., s. 163; A. Długosz, B. Stypułkowska, Wprowadzenie do dydaktyki biblijnej, dz. cyt., s. 115.

${ }^{57}$ Por. R. Kamiński, Biblia w życiu parafii i małych wspólnot religijnych, dz. cyt., s. 164-165.

${ }^{58}$ Por. A. Długosz, B. Stypułkowska, Wprowadzenie do dydaktyki biblijnej, dz. cyt., s. 92-112. 
niedzielę i tydzień biblijny ${ }^{59}$ oraz formy katechezy ewangelizacyjnej: Szkoły Słowa Bożego, Grupy słuchania oraz Katedra dla niewierzących ${ }^{60}$.

\section{Propozycje dotyczące przekazu treści biblijnych w parafii}

Przekaz treści biblijnych w parafii może mieć charakter liturgiczny półciągły, kursoryczny (ciągły) oraz tematyczny. Z przekazem treści o charakterze liturgicznym mamy do czynienia najczęściej podczas homilii oraz w czasie spotkań studyjnych grup lektorskich, gdy omawiane są fragmenty przeznaczone do czytania podczas liturgii słowa. Z przekazem treści o charakterze kursorycznym mamy do czynienia wówczas, gdy w jakiejś grupie czytane są i omawiane poszczególne księgi biblijne w sposób kursoryczny. Z przekazem treści o charakterze tematycznym mamy do czynienia wówczas, gdy omawiane jest wybrane zagadnienie występujące w Biblii. Charakter tematyczny zachowany będzie również wtedy, gdy dana grupa zapoznawana jest $\mathrm{z}$ wybranymi fragmentami, np. róże różańcowe mogą być zapoznawane z perykopami biblijnymi dotyczącymi tajemnic różańcowych.

Dla osób dorosłych uczestniczących w katechezie ewangelizacyjnej główną treścią katechezy biblijnej będzie Osoba Jezusa Chrystusa przedstawiana w Ewangeliach. Przekaz treści będzie miał charakter tematyczny.

Dla osób dorosłych uczestniczących w katechezie wtajemniczającej głównymi treściami katechezy biblijnej będą teksty przybliżające rzeczywistość sakramentu chrztu, bierzmowania i Eucharystii oraz historia biblijna przedstawiana na kanwie Starego i Nowego Testamentu. Przekaz treści również będzie miał charakter tematyczny.

Dla osób dorosłych uczestniczących w katechezie mistagogicznej głównymi tematami katechezy biblijnej będą treści przekazywane podczas liturgii słowa niedzielnych i powszednich mszy świętych. Przekaz treści będzie miał charakter liturgiczny.

Dla osób dorosłych uczestniczących w katechezie stałej główną treścią katechezy biblijnej będzie orędzie poszczególnych ksiąg biblijnych czytanych w sposób ciągły. Przekaz treści będzie miał charakter kursoryczny.

\footnotetext{
${ }^{59}$ Por. J. Kudasiewicz, Proforystyka pastoralna, dz. cyt., s. 270-271.

${ }^{60}$ Por. J. Kochel, Katecheza ewangelizacyjna w nauczaniu pastoralnym Carlo Maria Kard. Martiniego, Opole 1999, s. 177-218.
} 


\section{Wnioski}

Niniejszy artykuł podjął zagadnienie katechezy biblijnej skierowanej do osób dorosłych, czyniąc to w świetle obowiązujących dokumentów kościelnych i opracowań. Duszpasterstwo biblijne podejmowane w parafii obejmuje bowiem również katechezę biblijną. Winna być ona prowadzona dla różnych grup, w zależności od wieku i zaangażowania religijnego.

Katechezy dorosłych nie można ograniczyć jedynie do istniejących w parafii stowarzyszeń, bractw i ruchów katolickich. Należy proponować dorosłym katechezę w odrębnych grupach, w zależności od ich sytuacji. Można podzielić działalność katechetyczną prowadzoną w parafii na katechezę ewangelizacyjną, katechezę wtajemniczającą, katechezę mistagogiczną oraz katechezę stałą. Dorosły winien wiedzieć, jakie są główne treści poszczególnych rodzajów katechezy, aby mógł wybrać odpowiedni dla siebie cykl spotkań. Również duszpasterz może zasugerować uczestnictwo w określonej grupie. Katecheza okazjonalna prowadzona w parafii, głównie podczas udzielania sakramentów, może przybrać charakter ewangelizacyjny, zachęcający osoby niezaangażowane w życie parafii we włączenie się do którejś z istniejących grup formacyjnych.

Zaproponowano zorganizowanie w parafii trzech form katechezy biblijnej: form modlitewnych, studyjnych i mieszanych, w posługiwaniu się którymi można korzystać z różnorodnych metod biblijnych. W każdą z form katechezy biblijnej mogą być zaangażowani inni katecheci. Warto zauważyć, że katechetami osób dorosłych winny być osoby dobrze do tego przygotowane. Niekoniecznie musi to być kapłan pracujący w parafii. Dla każdej grupy katechizowanych (katecheza ewangelizacyjna, wtajemniczająca, mistagogiczna i stała) może być oddzielny katecheta. Zagadnienie formacji biblijnej katechetów wymaga oddzielnego opracowania.

\section{Abstrakt}

\section{Katecheza biblijna w parafii skierowana do osób dorosłych}

Niniejszy artykuł podejmuje zagadnienie katechezy biblijnej skierowanej do osób dorosłych w świetle obowiązujących dokumentów kościelnych i opracowań. Wzięto pod uwagę podstawowe dokumenty katechetyczne: adhortację apostolską Jana Pawła II o katechizacji w czasach współczesnych Catechesi tradendae, dokument Kongregacji ds. Duchowieństwa zatytułowany Dyrektorium ogólne o katechizacji, dokument Konferencji Episkopatu Polski zatytułowany Dyrektorium katechetyczne Kościoła katolickiego w Polsce oraz dokument Międzynarodowej Rady do Spraw Katechezy zatytułowany Katecheza dorosłych we wspólnocie chrześcijańskiej. Niektóre linie i ukierunkowania i następny dokument Konferencji Episkopatu 
Polski - Dyrektorium duszpasterstwa stużby liturgicznej. W artykule przedstawiono zagadnienie katechezy dorosłych w parafii ze zwróceniem uwagi na katechezę biblijną, wymieniono niektóre formy i metody katechezy biblijnej w parafii, a na końcu podano propozycje dotyczące przekazu treści biblijnych.

Słowa kluczowe: parafia, katecheza biblijna, katecheza dorosłych, formy biblijne, metody biblijne

\section{Abstract \\ Parochial Biblical catechesis intended for adults}

The present paper deals with the problem of biblical catechesis intended for adults in the light of the Church documents and studies. Basic catechetical documents were taken into account: the Apostolic Exhortation Catechesi Tradendae of Pope John Paul II on catechesis in our time, the document issued by the Congregation for the Clergy, entitled General directory for catechesis, the document of the Polish Episcopal Conference, entitled Catechetical directory of the catholic Church in Poland, as well as the document issued by the International Council for Catechesis, entitled Adult catechesis in the Christian community: some principles and guidelines, and the consecutive document of the Polish Episcopal Conference - Directory for pastoral care of liturgical ministers. The paper discusses the problem of adult catechesis in parish focusing on biblical catechesis. Selected forms and methods of biblical catechesis in parish were presented, followed by some propositions with respect to the presentation of biblical themes.

Keywords: parish, biblical catechesis, adult catechesis, didactic biblical forms, didactic biblical methods

\section{Bibliografia}

Długosz A., Stypułkowska B., Wprowadzenie do dydaktyki biblijnej, Kraków 2000.

Kamiński R., Biblia w życiu parafii i małych wspólnot religijnych, [w:] Biblia w nauczaniu chrześcijańskim, red. J. Kudasiewicz, Lublin 1991, s. 139-168.

Kochel J., Marek Z., Pedagogia biblijna w katechezie, Kraków 2012.

Kudasiewicz J., Proforystyka pastoralna. Pismo Święte jako księga Ludu Bożego, [w:] Wstęp ogólny do Pisma Świętego, red. J. Szlaga, Poznań-Warszawa 1986, s. 221-275.

Łabendowicz S., Katecheza dorosłych Kościoła posoborowego w świetle dokumentów i literatury katechetycznej, Radom 2007. 
Misiaszek K., Zagadnienie katechezy dorostych wedtug dokumentu „, Katecheza dorostych we wspólnocie chrześcijańskiej”, [w:] Katecheza dorostych we wspólnocie Kościoła, red. K. Misiaszek, Warszawa 2002, s. 49-60.

Murawski R., Działania katechetyczne w parafii w świetle Dyrektorium Ogólnego i Polskiego, [w:] Przestanie dokumentów katechetycznych Kościoła w Polsce, red. S. Dziekoński, Warszawa 2003, s. 55-70.

Tomasik P., Miejsce katechezy dorostych w duszpasterstwie polskim, [w:] Katecheza dorostych we wspólnocie Kościoła, red. K. Misiaszek, Warszawa 2002, s. 199-229. 